DOI: https://doi.org/10.47405/mjssh.v6i8.908

\begin{tabular}{|c|c|}
\hline 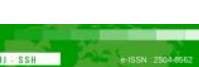 & Malaysian Journal of Social Sciences and Humanities (MJSSH) \\
\hline Malaysian Journal of & Volume 6, Issue 8, August 2021 \\
\hline $\begin{array}{l}\text { Humantites } \\
\text { (MJ-sSH) }\end{array}$ & e-ISSN : 2504-8562 \\
\hline & $\begin{array}{l}\text { Journal home page: } \\
\text { www.msocialsciences.com }\end{array}$ \\
\hline
\end{tabular}

\title{
Restructuring State - Local Relations in Nigeria: Issues and Perspectives
}

\author{
Nuruddeen Muhammad Koko',2, Azmil Mohd Tayeb ${ }^{2}$, Siti Zuliha Razal ${ }^{2}$ \\ 1Department of Public Administration, Usmanu Danfodiyo University, Sokoto, Nigeria \\ 2Department of Political Science, School of Social Sciences, Universiti Sains Malaysia (USM), Malaysia
}

Correspondence: Nuruddeen Muhammad Koko (nmuhammadkoko@gmail.com)

\begin{abstract}
Federations thrived where levels of government exist and function based on shared rule and self-rule concurrently. Thus, a key defining feature of federalism is the assignment of responsibilities between component units such that each unit is assigned specific responsibilities within its jurisdiction. However, in Nigeria, the disproportionate distribution of responsibilities and resources amongst the component units had resulted in a dysfunctional federation. By virtue of the provision of section 7 of 1999 Constitution, Supreme Court's judgements and extra-judicial pronouncements, local governments are under the "supervisory control" of the State Governments (SGs). However, the extent to which this supervisory control is exercised has been at the front burner of every discourse on Nigerian politics and particular governance challenges. While examining state-local governments relations from both legal and operational viewpoints, this paper illustrates how the SGs wore away the intent of the framers of the Constitution, which is to institute a system of local government that is properly organised, monitored supervised by the SGs. A qualitative research approach was used. Data was collected via official documents, relevant literature, and interviews from officials of the SGs and local governments and experts selected purposively and conveniently. The paper established that local governments are failing simply because the SGs have failed to perform their responsibilities per the spirit of the Constitution and other extant laws. The article finally advocates for an efficient and effective local government system premise on the federal decentralise system. In doing that, it is important to stress that the existing legal aspect does require slight adjustment especially granting the Houses of Assembly of State and state judiciary reasonable autonomy to checkmate the excesses of the SGs. Moreover, accomplishing this will significantly restructure and improve the operational aspect of the relationship for a virile local government system.
\end{abstract}

Keywords: local governments, local government autonomy, restructuring, intergovernmental relations

\section{Introduction}

Generally, local government system is classified implicitly on the relation of local to national government within a country (Wolman, 2008). Thus, in the case of Nigeria, the 1999 Constitution clearly specified the relationship between the local governments (LGs) of a State and other tier of government. Basically, it is made noticeably clear that LGs are under the control of the SGs in virtually every ramification. Section 7 (1-6) provides for a system of local government by democratically elected Local Government Councils, and accordingly, the Government of every State shall ensure their existence under a law which provides for their establishment, structure, composition, 
finance, and functions. Further to this, the LGs are mandated to participate in the economic planning and development in the State. Thus, they shall participate in the Government of the State as respects to the provision and maintenance of primary, adult and vocational education, the development of agriculture and natural resources, provision and maintenance of health services, and such other functions as may be conferred by the House of Assembly (CFRN, 1999). Thus, to a significant degree, responsibilities of SGs and LGs are overlapping towards providing services and to virtually single group of beneficiaries. Therefore, these provisions alluded to the fact that LGs are an annexure to the SGs. They are under the strict supervision of the SGs in terms of fiscal management, it is the business of the SGs to organize, supervise and to monitor their finances, and to an extent staffing. Accordingly, Uwais (2005) affirmed that a close examination of the relevant provisions of the 1999 Constitution, shows that the supervision of LGs is the responsibility of the SGs.

In the same way, section 162 (6) of the 1999 Constitution provides that each State shall maintain a special account to be called 'State Joint Local Government Account' (SJLGA) into which shall be paid all allocations to the LGs of the State from the FA and from the Government of the State. Although, there have been controversies as to whether the SGs are trustees of the SJLGA or channels for transmitting the funds to their respective local governments. However, just as Olowu (1986) opined local governments are in worse position of dependency, but this is more pronounced and pathetic since the return to civil rule in 1999 (because the 1999 Constitution share similar provisions with the 1979 Constitution). Local government system since the return to civil rule in 1999 had become a subject of national debate among scholars and practitioners. Hence, several studies by World Bank (2002), Akindele, Olaopa, and Obiyan (2002), Asaju (2010), Daniel (2012), Wilson (2013), and Abdulhamid and Chima (2015) observed the dwindling performance of local governments in Nigeria as democratic institutions and grassroots institutions for service delivery. Perhaps, this explains why the National Assembly in all the efforts to amend the 1999 Constitution, focused (although unsuccessful) on granting local government autonomy.

In view of these, the purpose of this paper is to examine state-local governments relations in Nigeria from both the legal and operational viewpoints, and to set our understanding of the ongoing clamour for restructuring and granting local governments autonomy. Hence, following this introduction, is an overview of the history of local government system in Nigeria. Next it discusses the functional responsibilities of LGs and fiscal intergovernmental relations between SGs and LGs, which is followed by discourse on complexities of local government control. Lastly, in the concluding section it offers recommendations for restructuring state-local relations towards promoting cooperation and coordination and enhancing the participation of local governments in responding to the challenges ravening Nigeria.

\section{Understanding Local Governments in Nigeria: An Overview}

Local governments (LGs) are governments at local levels through representative councils established by law that exercise specific functions within defined areas so as to complement the activities of superior levels of government. Boadway and Shah (2009), defined LGs as specific institutions or entities created by national constitutions (Brazil, Denmark, France, India, Italy, Japan, Sweden), by state constitutions (Australia, the United States), by ordinary legislation of a higher central government (New Zealand), the United Kingdom, most countries), by provincial or state legislation (Canada and Pakistan) or by executive (China) to deliver a range of specified services to a relatively small geographically delineated area. Thus, LGs in Nigeria evolve in the mould of Native Authorities (NA), that administer areas possibly homogenous in respect of the ethnic and linguistic features of their population. The Native Authority normally consists of a chief (usually an Emir, Oba, or Chief) associated with a council which may consist of members ex-officio and nominated and may include elected members. The Native Authority vary greatly in area, population, and administrative systems. Hence, the Native Authority Law was designed broadly to allow for the variations of their organizations, procedure, and functions. 
Yahaya (1980), opined that the Native Authority as the unit of local government was supported by a bureaucratic organization known as the Native Administration. Then, the functions of the Native Authority were solely the maintenance of law and order and collection of taxes. Further to these, the Authority provides social services such as education, electricity, water supply, access roads, motor parks, and residential accommodation. Thus, the Native Authority maintains the local administration, treasuries, native courts, police and prisons, agriculture, animal husbandry, and forestry and conduct some capital works. Giving the dominance of the traditional institutions in the administration of the Native Authority, there were persisted agitations for reforms with a view to altering the basis of political participation in order to give room for wider participation. Modern Local Governments, therefore, according to Odoh (1991) appeared on the Nigerian scene with the advent of the Macpherson Constitution that provided for a quasi-federal system of government.

The composition of the Country then, that is consisting of Regional Governments; made local governments part of regional affairs with each region designing its own administrative structure. Thus, until the 1976 Local Government reforms, there was no uniform system of local government in the country. Therefore, subsequent changes in the structure and operations of the LGs were carried out by the respective regions in tandem with their social, economic, and traditional features. In the views of Adeyemi (2019), the Eastern Region was the first in 1950 to initiate a radical change in the operation and administration of Local Government with the promulgation of the Eastern Regional Local Government Ordinance. A three-tiered representative local government system was introduced. The Western Region also tried to enhance popular participation with elected councillors constituting a majority in the Councils. Consequently, the term NA was replaced with Local Government administration, and colonial officers were stripped off their functions of inspection, supervision, and control to a mere advisory. Whereas, in the North, far-reaching administrative reforms were made but left the structures unaffected. The retention of the structure though with slight adjustments to allow popular participation was aimed at maintaining the socio-political stability of the region giving the success of the indirect rule system owing to the strong entrenchment of the traditional institutions in the region. Thus, Odoh (1991) documented the hesitation in the North to embrace outright popular participation and therefore had to choose cautions and 'gradualist' approach to reforms.

The term Native Authority was abolished and replaced variously by local government authority, local administration, or local administrative areas. Thus, new, and more representative bodies were instituted consisting of two-third elected and one-third nominated members in the North Central State. However, due to the ban on political activities, all the members who would otherwise have been elected, were nominated by the Military Governor on the recommendations of the provincial administration. Similarly, the functions of maintaining law and order were altered especially with the taking over of Area Courts by the States and the Prisons by the Federal Military Government. Therefore, in line with the radical changes in the structure and organization, LGs functions and scope were broadened in order for them to become development oriented. Hence, the LGs were saddled with the responsibilities of ensuring the economic and social development of their areas of jurisdiction.

With regards to local government finances, it is important to highlight the long history of local finances and taxation since 1900. There were Native Treasuries established in 1911 with standardised treasury accounting procedures that were controlled through rules known as Financial Memoranda, which was formerly issued by the Regional Ministry for Local Government, and now under the direction of the State Governments. Control of treasuries is exercised by the local government division of the Military Governor's office, or the Ministry for Local Government established in each State. All Local Authority estimates require the approval of the State Government, and the inspection of Treasury Accounts is conducted both by the cadre of local government officers and the state audit departments. The most important revenues for the Native Authority are the Community Tax levied on every adult male resident of the community, the cattle tax paid on specific livestock in the Native Authority, and the Personal Income Tax. In addition to this, Native Authorities do also receive Grants in Aid from the Regional Governments.

In 1976, local government reform was considered an integral part of the Political Programme of the Federal Military Government. Thus, the reforms were considered necessary in the process of building 
a sound foundation for the return to civil rule slated in 1979. This informed the decision by the Federal Government to intervene in what was hitherto an exclusive reserve of the State Governments. Hence, the Federal Government embarks on the 1976 Local Government reform but through extensive consultation with the SGs. However, Olowu (1986) lamented, a fair success recorded in the first few years of the reform just before the return to civil rule in 1979. According to Odoh (1991), local governments suffered the most severe damage during this period. The State Governments owing to the provisions of Section 7 freely encroached and undermined LGs in all facets. This is further aggravated by the outright disregard of the 1979 Constitution such that no election was held at the LGs throughout the Second Republic (1979-1984). In addition, the State Governments went on creating additional LGs without regards to the reform guidelines on the creation of new LGs.

The highlighted challenges coincided with the collapse of the Second Republic and the new Military Government of 1984 inaugurated a Committee under the Chairmanship of Alhaji Ibrahim Dasuki to review the local government system in Nigeria. The Committee affirmed and endorsed most of the provisions of the 1976 reforms with few modifications. The reform suggested a ten-year interval for the creation of additional LGs taking into consideration factors such as minimum taxable population and financial viability. Far-reaching recommendations of the reform were on the need for both the Federal, States, and LGs to share the burden of funding primary education as against the prior practice of letting the burden on the LGs. In affirming the recommendations of the reform, the FG embarked on the direct allocation of statutory allocations from the Federation Account (FA) to the LGs. Also, the hitherto spending limits imposed by the SGs on LGs were lifted. There was also an upward review of statutory allocation from the FA to the LGs from 10\% in 1990 to $15 \%$ and later $20 \%$ in 1992. This was also followed by $35 \%$ of Value Added Tax (consumption tax on goods and services) revenues.

The Military once again supervised another transition to civil rule in 1999, with a constitution that is virtually a replica of the 1979 Constitution. The 1999 Constitution retains all the provisions of the 1979 Constitution pertaining to the local government system. It recognises the LGs as the third tier of government, controlled by the State Governments; and grants them statutory allocation from the FA and a certain percentage of the revenues of the States. The erstwhile controversial joint account was also retained. Similarly, the first and fourth schedules of the Constitution contained the names and the functions of the LGs. In addition, a State Independent Electoral Commission was established by the Constitution and was saddled with the responsibility of conducting LG elections. However, going by events across the country since the return to civil rule in 1999, it is inevitable to ponder and ask what should be done to ensure a viable local government system that is capable of harnessing local resources towards effective and efficient service delivery? Answers to this will be the focus of the subsequent sections.

\section{Functional Responsibilities of LGs in Nigeria}

Discourse on revenue allocation inevitably must examine the functional responsibilities of levels of government. Accordingly, Watts (1996) argued that the specific form and allocation of the distribution of powers has varied relating to the underlying degrees and kinds of common interests and diversity within the society in question. Therefore, each level of government in a federation is assigned responsibilities in consideration of the basic principle of shared rule and self-rule. In view of this, Nasir (2012) observed that the 1999 Constitution provides an exclusive list of central powers, a concurrent list of shared powers, with all residual powers going to the States and a fourth list of LG functions. Despite, section 7 (1) mandates States to ensure the existence of LGs under a law which provides for the establishment, structure, composition, finance, and functions; the Fourth Schedule further listed the main functions of the LGs. Therefore, whilst the States are required to specify the functions of their LGs in their various laws, it expected such specified functions to take cognizance of the ones stated in the Fourth Schedule. Thus, the main functions of a LG as specified in the 1999 Constitution are as follows:

i. Consideration and the making of recommendations to a state commission on economic planning or any similar body on (i) the economic development of the State, particularly in so 
far as the areas of authority of the LG and of the State are affected, and (ii) proposals made by the said commission or body.

ii. Collection of rates, radio, and television licences.

iii. Establishment and maintenance of cemeteries, burial grounds, and homes for the destitute or infirm.

iv. Licensing of bicycles, trucks (other than mechanically propelled trucks), canoes, wheelbarrows, and carts.

v. Establishment, maintenance and regulation of slaughterhouses, slaughter slabs, markets, motor parks and public conveniences.

vi. Construction and maintenance of roads, streets, street lightings, drains and other public facilities as may be prescribed from time to time by the House of Assembly of a State.

vii. Naming of roads and streets and numbering of houses.

viii. Provision and maintenance of public conveniences, sewage and refuse disposal.

ix. Registration of all births, deaths, and marriages.

x. Assessment of privately owned houses or tenements for the purpose of levying such rates as may be prescribed by the House of Assembly; and

xi. Control and regulation of: (i) outdoor advertising and hoarding, (ii) movement and keeping of pets of all description, (iii) shops and kiosks, (iv) restaurants, bakeries, and other places for sale of food to the public, (v) laundries, and (vi) licensing, regulation, and control of the sale of liquor (CFRN, 1999).

In addition to these functions, LGs shall participate in the Government of a State as respects the following matters:

i. The provision and maintenance of primary, adult, and vocational education.

ii. The development of agriculture and natural resources, other than the exploitation of mineral resources.

iii. The provision and maintenance of health service; and

iv. Such other functions as may be conferred on a LG by the House of Assembly of the State.

To this end, LGs legislature have powers to make byelaws for the realisation of all the functions. However, matters on the concurrent between the States and the LGs can only be legislated upon when granted such powers by the House of Assembly of the State. The extent to which the LGs discharged these functions have been greatly questioned by many stakeholders ranging from policy makers, academicians, civil societies, and development partners. However, it has also been expressed in several quarters that there is the need to devolve some responsibilities to the LGs and this is very necessary and particularly important too.

\section{State-Local Governments Relations: Symbiosis or Predacity}

Jurisprudentially, State Governments are required to ensure a system of LG by democratically elected Local Government Councils, and accordingly, the Government of every State shall ensure their existence under a law which provides for the establishment, structure, composition, finance, and functions. Further to this, the LGs are mandated to participate in the economic planning and development in the State. Thus, they shall participate in the Government of the State as respects to the provision and maintenance of primary, adult and vocational education, the development of agriculture and natural resources, provision and maintenance of health services, and such other functions as may be conferred by the House of Assembly. Thus, to a significant degree, responsibilities of SGs and LGs are overlapping towards providing services, and to virtually single group of beneficiaries.

While this is the case, what is tenable now in all the SGs, local governments in Nigeria are under the supervisory control of the State Governments. According to Gboyega (1981), LGs are, as defined in the Constitution part of the public service of a State to be established by a Law of a House of Assembly. Similarly, Ebeku (1992) cited Nwabueze a famous Constitutional expert arguing that LGs are not independent third tier of government, but only an agency or creation of the SGs. However, 
going by the antecedents of the SGs in the exercise of this supervisory control, it is described as near omnipotent, and going by the laws passed by the Houses of Assembly, it can be said to have hindered the smooth operations of LGs. The SGs not only captured but capitalise on certain laws that had given them certain powers to stunt the growth of LG institutions in Nigeria. Also, the laws made by the Houses of Assembly with respect to the LGs, curtailed projects execution by the LGs. Similar observation was made by Adetiba (2017) that LGs in Nigeria would not be able to exercise their Constitutional functions until the Houses of Assembly passed a law. Again, Vambe (2018) opined that LGs had continued to suffer as SGs often abuse their supervisory powers.

Another essential point is the fiscal constraints local governments are facing in Nigeria. This, constraint is associated to inability to administer own taxes, and overdependence on fiscal transfers from the Federation Account. First, the SGs have substantial influence in deciding the tax rates to be collected by the LGs. Secondly, the location and economic activities in most of the LGs will not warrant the LGs to raise any substantial revenue. This problem added to other related issues such as traditional values and religion does not support optimal revenue collection. Therefore, except for local market activities many rural LGs do not have a tax base. Thus, going by the typical idea of taxation system, the philosophy of taxation that is guided on economy, equity, certainty and convenience, most LGs in Nigeria (both urban and rural) are found to have similar treasury systems in terms of revenue administration. Therefore, having similar system of revenue administration across board is not only elusive, futile but also uneconomical as described by Adam Smith's 'maxims' of taxation. Smith (1776: 1044) held that 'every tax ought to be so contrived as both to take out and keep out of the pockets of the people as little as possible over and above what it brings into the public treasury of the State'.

Until 2002, LGs in Nigeria received their statutory allocation from the FAAC directly through the Office of the Accountant General of the Federation (OAGF) following a Supreme Court judgement (see AG Ogun V AG Federation 2002, 10, NWLR 232), their allocations started going through their respective SGs. Thus, it has been established that the SJLGA into which statutory allocation due to LGs, is the responsibility and the function of the government of the States to maintain as enshrined by section 162 (6) of the 1999 Constitution. The section provides that each State shall maintain a special account to be called 'State Joint Local Government Account' (SJLGA) into which shall be paid all allocations to the LGs of the State from the FA and from the Government of the State.

The SJLGA therefore, is a special account established and maintained by the SGs for the purpose of receiving statutory allocation due to their LGs from the FA and the $10 \%$ contribution from the States' IGR. However, controversies trailed whether the SGs are trustees of the SJLGA or channels for passing funds allocated to their respective LGs? It was held by many that the SG is merely a channel for passing the funds allocated to LGs for onward distribution to the respective LGs in the State. In other words, the SJLGA is made for convenience to transmit LG allocations. It is a collection account for the purpose of distributing the statutory allocations to the LGs. Also, the system is not design for the SGs to only receive and decide what to give to their respective LGs, but it must follow the relevant laws especially the Revenue Allocation Act and the Laws passed by the State House of Assembly. It is also reasoned that the SJLGA is meant for the States to also contribute $10 \%$ of their IGR to their respective LGs.

On the contrary, it was argued that the account is meant to streamline the economies within states. This, it was opined, several LGs for instance will find it difficult to meet their salary obligations if not for the joint account. Thus, the essence of the account, it was argued is to ensure no LG is left behind in terms of meeting its obligations especially pertaining payment of salaries. Further to this, it was presented that there are joint projects finance by both the State and its respective LGs to finance projects beyond the capacity of the LGs. Thus, the essence is to have a balancing act such that those LGs that are buoyant enough can take care of those that are not well provided for.

Regardless of the proprietary right over the SJLGA, by virtue of section 7 (6) (b) and section 162 (6), (8), the account is within the exclusive purview of the SGs to establish and maintain. However, considerable concern is shown in the way the States managed the account. The Former Speaker House 
of Representative Yakubu Dogara described the SJLGA as 'one of the biggest evils' (Ogundipe, 2016). Also, the Technical Committee on the Review of the Structure of LGs in Nigeria in 2003 observed the SJLGA had caused so much dissatisfaction between SGs and LGs thereby affecting programme implementation. The Committee further expressed the magnitude of the problem giving the disparity between the LGs' share of the FA and what really went to the LGs. It concluded that the operation of the SJLGA by the SGs tended to be to the disadvantage of the LGs (FGN, 2003). Likewise, Wilson (2013) raised concerns over the abuse of LGs funds by the SGs through the SJLGA. Also, Doho et al (2018) opined that the SGs do deny LGs the funds that are due to them. Similar views were expressed by Festus, et al (2017) that the SGs are crippling LGs financially by inexplicable deductions or unduly delaying the release of funds from the SJLGA.

The foregoing suggests that there are flagrant abuses of the SJLGA by the SGs such that LGs do not get their funds and even when they do, it is like a case of I give you your money and you come back and give it to me in another way. These abuses, to an extent are attributed to lack of sincerity of purpose and transparency in dealing with LG funds by the SGs such that, the SGs do not distinguish their funds with those belonging to their LGs. Consequently, the SGs are truly benefiting from the SJLGA thereby withholding, tempering with the allocation, determining, and making undue deductions. Thus, even though, there are enough justifications for the continuous existence of the SJLGA, yet evidence have revealed that the inordinate deductions made by the SGs and indeed, the management of the SJLGA had resulted in variations in the revenue allocation framework with the statutory distribution of revenue to the LGs.

Next, is the challenge of corruption which had significantly hindered revenue collection and utilization in Nigeria. The little revenue collected by revenue collectors rarely end up into the LGs' accounts. Related to this also is the problem of tax evasion. It is disturbing for instance in Kano State with an estimated population of $13,076,892$ people but raising revenues of less than $\$ 300$ per capita in a year. According to Gboyega (2011), LGs taxable resources compared to other levels of government, are with the least yield potential, quite expensive to collect and easy to evade. Thus, even where the base is there, the capacity to raise the taxes and remit same into the accounts constitute a great challenge to most LGs in Nigeria. Therefore, often the actual collections are far below the potential collection. In addition to the challenges of corruption, tax evasion and capacity of the revenue personnel, religious and cultural practices, nature of economic activities, location of the LGs and often political influence have seriously paralysed revenue collection by LGs.

Giving these challenges, the SGs are making efforts to enhance internal revenue generation efforts of their respective LGs. The concerns are on how to reconcile tax base with tax rates. Because having a single tax rate had resulted in what Bird and Smart (2002) conceived as 'undesirable incentive effects' where LGs with least tax base may not generate what LGs with average tax base are likely to generate. In most States, the term taxes are substituted with rates and levies for local governments. This is with a view to harmonised rates and levies charged by the LGs in the States based on certain peculiarities, specifically geography and economic activities. Thus, the LGs in the State were categorised in to three: Urban; Semi Urban and Rural. Then, all levies and rates to be charged by a local government is pegged based on the category each falls.

\section{Conclusion}

Whilst the importance and autonomy of local governments has varied enormously from federation to federation, it has been the tradition of most federations to assign the determination and the scope of power of local governments to the intermediate state governments (see Watts, 1996). In Nigeria, despite local governments are creation of the National Constitution, yet their establishment, structure, composition, finance, and functions are the responsibility of their respective State Governments through laws passed by the Houses of Assembly of a State. Therefore, the success of local governments in Nigeria depends in large measure upon their respective SGs. Thus, in examining the state-local governments relations in Nigeria it has been shown that local governments have failed and are continuously failing. For that reason, local governments failed because the SGs have not been 
performing the responsibilities assigned to them by the Constitution. This is in line with the submissions of Bahl and Linn (1994) who argued that LGs in developing countries are bedevilled by series of controls by the higher levels of government. As such, in Nigeria, local governments are excessively controlled by the SGs through budget approvals, appointment of officials, regulation of tax administration etc. Also, there is the challenge of fiscal dependency syndrome in which LGs are entirely dependent on tax rates been fixed by the SGs; every expenditure is authorised by the SGs; and overdependent on fiscal transfers. In sum, the SGs are benefiting from the existing legal and operational fiscal arrangement by rendering LGs in a state of helplessness, not capable of rendering any services without resorting to the SGs.

The ongoing agitations for restructuring and granting local governments autonomy are not unconnected with the failure of the SGs to monitor their respective local governments effectively and efficiently. Therefore, in order for local governments to function as envisaged in a decentralised federal system, it becomes essential to restructure how best SGs should relate with their respective local governments. However, it must be emphasised the ongoing agitations for granting local governments autonomy is misconstrued. Therefore, any attempt to restructure state-local relations must take cognisance of the intendment of section 7 of the 1999 Constitution, which is to instil cooperation and coordination between the SGs and local governments. Thus, while some legal aspects too require amendments, most fundamentally, it is the operational aspect of the state-local relations that is requiring restructuring.

Notwithstanding the concerns of Jorge and Smoke (2011) that the road to instituting efficient and effective local government system has been far from smooth or easy, and many challenges persist to various degrees; this paper offers the following modest recommendations: The efforts by the Federal Government to ensure Houses of Assembly of State and the States judiciary enjoy relative autonomy as been enjoyed by the similar institutions at the federal level should be pursued and accomplished. This, way the institutions will checkmate the excesses of the SGs and ensure conformity with enabling laws. Secondly, the National Assembly should proceed with caution, the Constitutional amendment, because it still baffles many as to why the advocates of granting local governments autonomy are often the former Governors in the presently in the Senate. This is because the functions of the SGs and local governments are interwoven and complementary. As such it is inevitable when discharging their assigned responsibilities to cooperate concurrently in areas such as primary health care, basic education, roads, agriculture, and other too numerous socioeconomic and political goals. Moreover, based on the ideas of Boadway and Shah (2009), local governments are extensions of state governments, ... depending on their constitutional and legal status, state governments in federal countries assume varying degrees of oversight of the provision of local public services. Third, local governments tenure must be defined and stated in the constitution so as to checkmate the frequent distortion and disruption of governance caused by the SGs who often substitute elected councils with their personal appointees without regards to due process.

Lastly, it is apt to reiterate here that local governments are multipurpose government in Nigeria because they bear the burden of people much more than the SGs and the FG. This is obviously due to their closeness with the people that look up to them for empowerment programmes, primary health centers are stocked and staffed, education, basic social services (water, sanitation, agriculture, and forestry), and other capital projects especially street lightening, roads, planning and public conveniences. However, providing these basic services have been challenged by lack of correspondence between available revenue and expenditure responsibilities. Therefore, the practice in which the SGs dictate and determine every undertaken by their respective local governments is only aggravating the challenge of poverty of leadership bedevilling the country. Thus, it is imperative to restructure state-local relations such that SGs will be mandated to a great deal offer financial and technical support and to monitor the ways in which both human and material resources are used by the LGs. 


\section{References}

Abdulhamid, O. \& Chima, P. (2015). Local Government Administration in Nigeria: The Search for Relevance. Commowealth Journal of Local Governance, 18: 4850 Retrived from http://epress.lib.uts.edu.au/ojs/index.php/cjlg .

Adetiba, T. C. (2017). Existentiality of Local Government inNigeria an Answer to Grassroots Development, but for Unsolicited Socio-Political Factors. AUDA, 9 (2) 25-46. Retrieved from http://journals.univ-danubius.ro/index.php/administratio/article/view/4615

Adeyemi, O. O. (2019). Local Government Administration in Nigeria: A Historical Perspective. Journal of Public Administration and Governance. Vol.9, (2).

Akindele, S. T., Olaopa, O. R. \& Obiyan, A. S. (2002). Fiscal Federalism and Local Governmnet Fiance in Nigeria: An Examination of Revenue Rights and Fiscal Jurisdiction. Internaational Review of Administrative Sciences, 68(4). Retrieved https://journals.sagepub.com/doi/pdf/10.1177/0020852302684004

Asaju, K. (2010). Local Government Autonomy in Nigeria: Politics and Challenges of the 1999 Constitution. International Journal of Advanced Legal Studies and Governance, I (1).

Attorney-General, Ogun State v Attorney-General of the Federation (2002) 18 NWLR (Pt. 798) 232.

Bird, R. M. \& Smart, M. (2002). Intergovernmental Fiscal Transfers: International Lessons for Developing Countries. World Development, 30(6), 899-912.

Boadway, R. \& Shah, A. (2009). Fiscal Federalism: Principles and Practice of Multiorder Governance. Cambridge University Press, New York.

CFRN (1999). Constitution of the Federal Republic of Nigeria

Daniel, A. T. (2012). Fluidity in Democratic Local Governance: The Achilles' Heel of Nigerian Local Government. Inkanyiso, Journal of Humanities \& Social Science, 4 (2). Retrieved from https://www.ajol.info/index.php/ijhss/article/view/86869.

Doho, A. W., Ahmed, A., \& Umar, A. (2018). Local Government Autonomy in Nigeria: Struggles and Challenges. Advances in Social Sciences Research Journal, 5(5) 44-51. DoI: 10.14738/assrj.55.4498.

Ebeku, K. S. A. (1992). The Separation of Powers in Local Government in Nigeria. Journal of African Law, $36(1), 43-51$.

Festus, I \& Mustapha, A. I (2017). Challenges to Local Government as a Developmental Paradigm in Nigeria. Local Government Quarterly, LXXXVII (3), 35-48.

FGN (2003) Report of the Technical Committee on the Review of the Structure of Local Government Councils in Nigeria: Volume 1 Findings and Recommendations.

Gboyega, A. (2011). Democratization and Local Governance in Nigeria Since 1999. Retrived from https://www.researchgate.net/publication/237289441-Democratization-And-Local-Governancein-Nigeria-since-1999-by/citation/download

Gboyega, A. (1981). Intergovernmental Relations in Nigeria: Local Government and the 1979 Nigerian Constitution. Public Administration and Development, 1, 281-290.

Jorge, M. \& Smoke, P. (2011) Introduction to Local Government Finance: The Challenges of the $21^{\text {st }}$ Century. Economics Faculty Publications. Paper 55. Available at:https://scholarworks.gsu.edu/cgi/viewcontent.cgi?article=1056\&context=econ facpub

Nasir, J. (2012). The Distribution of Powers and Responsibilities in the Federal Republic of Nigeria. African Journal of Federal Studies. 2 (1). 25-56.

Odoh, A. (1991). Local Government and Democracy in Nigeria. Background Papers Prepared for the Workshop on Legislative/Council Secretariate Functions and Procedures Commissioned by the Local Government Inspectorate Department Office of the Deputy Governor, Katsina State.

Ogundipe, S. (2016, November 30). State-Local Gov;t. Joint Account Must be Abolished. Premium Times

Olowu, D. (1986) A decade of local government reform in Nigeria: 1976-1986. International Review of Administrative Sciences, 52: 287-299. Available at:https://journals.sagepub.com/doi/pdf/10.1177/002085238605200302

Smith, A. (1776) The Wealth of Nations. Bantam Dell, New York, New York. 
Uwais, M. L. (2005). The Evolution of Constitutionalism: The Role of the Supreme Court under the 1979 and 1999 Constitution. Inaugural Distinguished Fellow Lecture, The Nigerian Institute of Advanced Legal Studies, Lagos, Nigeria.

Vambe, J. T. (2018). State-Local Relations in Nigeria and its Implication on Public Service Delivery at the Local Government Level. American Research Journal of Humanities Social Science, 01(04), 01-09. Retrieved from https://www.arjhss.com/wp-content/uploads/2018/12/A130109.pdf

Watts, R. L. (1996). Comparing Federal Systems in the 1990s. Institute of Intergovernmental

Relations. Queen's University Kingston, Ontario, Canada. Retrieved from http://www.queensu.ca/iigr/sites/webpublish.queensu.ca.igrwww/files/siles/pub/archive/book/co mparingFederalSystemsInThe1990s-Watts.pdf

Wilson, G. (2013). The Politics of Local Government Reforms and Democratic Governance in Nigerian Local Governments. Developing Country Studies, 3 (1). Retrieved from https://www.iiste.org/Journals/index.php/DCS/article/view/3892/3950

Wolman, H. (2008). Comparing Local Government Systems across Countries: Conceptual and Methodological Challenges to Building a Field of Comparative Local Government Studies. Environmental and Planning C: Government and Policy, 26, 87-103.

World Bank (2002) Nigeria: State and Local Governance in Nigeria (English). Washington, DC: Wotld Bank. Retrieved from http://documents.worldbank.org/curated/en/442501468780898611/Nigeria-state-and-localgovernance-in-Nigeria.

Yahaya, A. D. (1980). The Native Authority Sysytem in Northern Nigeria, 1950-1970: A Study in Political Relations with Particular Reference to the Zaria Native Authority. Ahmadu Bello Zaria University, Press. 